\title{
Paudorf locus typicus [Lower Austria] revisited - The potential of the classic loess outcrop for Middle to Late Pleistocene landscape reconstructions
}

\author{
Tobias Sprafke, Birgit Terhorst, Robert Peticzka, Christine Thiel
}

How to cite:

Sprafke, T., Terhorst, B., Peticzka, R., Thiel, Ch. (2013): Paudorf locus typicus (Lower Austria) revisited - The potential of the classic loess outcrop for Middle to Late Pleistocene landscape reconstructions. - E\&G Quaternary Science Journal, 62 (1): 59-72. DOI: $10.3285 /$ eg.62.1.06

Abstract: The more than $12 \mathrm{~m}$ thick loess-paleosol sequence in Paudorf, Lower Austria, has been known for decades as locus typicus of the
"Paudorfer Bodenbildung" (Paudorf paleosol). The upper section of the outcrop contains an up to $1 \mathrm{~m}$ thick pedocomplex that de-
veloped during MIS 5. The differentiated sequence of loess-like sediment below, including a more than $2 \mathrm{~m}$ thick pedocomplex in its
basal part, is an exceptional archive of landscape evolution from the Middle Pleistocene. Herein we present detailed paleopedologi-
cal and sedimentological surveys, as well as first micromorphological observations to address the sequence in its entirety and the
processes leading to its genesis. Furthermore, high resolution color and carbonate analyses, as well as detailed texture analyses,
have resulted in a substantial database.
The studies show that the loess sediments were subject to a polygenetic development under periglacial conditions reflected in eolian
silt and fine sand accumulation, admixture of local material during (mostly solifluidal) redeposition and in situ processes. Horizons
with signs of pedogenesis, particularly the two pedocomplexes, document longer phases of stability; the stages of development can
be correlated to equivalent sequences and seen as paleoclimatic signals where chronological data are available. The upper pedo-
complex is a Chernozem of the early last glacial (MIS 5c-[a?]), which developed in a solifluidal redeposited (MIS 5d) interglacial
Cambisol (MIS 5e). Cryosols, typical for MIS 6 sequences, are present in the loess sediment below. The lower pedocomplex formed
during several warm stages of varying intensities, with interruptions caused by colluvial processes and admixture of eolian sedi-
ment during colder stages.

Paudorf locus typicus [Niederösterreich] - Das Potential des klassischen Lössaufschlusses für die Rekonstruktion mittelbis spätpleistozäner Paläoumwelten

Kurzfassung: $\quad$ Die über $12 \mathrm{~m}$ mächtige Löss-Paläoboden-Sequenz in Paudorf (Niederösterreich), ist seit Jahrzehnten bekannt als locus typicus für die „Paudorfer Bodenbildung“. Dieser $1 \mathrm{~m}$ mächtige Pedokomplex im obersten Profilabschnitt entwickelte sich eem- bis frühwürmzeitlich. Das differenzierte Lösssediment im Liegenden, mit einem über $2 \mathrm{~m}$ mächtigen Pedokomplex im basalen Bereich, stellt ein außergewöhnliches Archiv mittelpleistozäner Landschaftsentwicklung dar. Die paläopedologischen und sedimentologischen Untersuchungen sowie erste mikromorphologische Analysen widmen sich erstmals der Gesamtabfolge und den Prozessen, die zu ihrer Entstehung beitrugen. Farb- und Karbonatanalysen in hoher Auflösung sowie detaillierte Korngrößenanalysen dienen dabei als hilfreiche Datenbasis.

Die Untersuchungen zeigen zum einen, dass die Lösssedimente einer komplexen Genese unter periglazialen Bedingungen unterlagen. Neben äolischer Akkumulation spielten (zumeist solifluidale) Umlagerungsprozesse unter Einmischung von lokalem Material ebenso wie in situ Prozesse eine Rolle. Morphodynamisch stabile Phasen sind insbesondere in den beiden Pedokomplexen nachweisbar. In Bereichen, in denen Datierungen vorliegen, können Entwicklungsphasen mit jenen anderer Sequenzen korreliert werden und als klimatische Signale interpretiert werden. Die „Paudorfer Bodenbildung“ ist vermutlich eine frühglaziale Humuszone (MIS 5c[-a?]), die sich in einer solifluidal umgelagerten (MIS 5d) eemzeitliche Braunerde (MIS 5e) gebildet hat. Im Lösssediment konnten Nassböden nachgewiesen werden, wie sie typisch für spätrisszeitliche (MIS 6) Sequenzen sind. Der untere Pedokomplex wurde offenbar über mehrere Warmphasen verschiedener Intensitäten hinweg gebildet und wiederholt von Umlagerungsprozessen und äolischer Sedimentation während Kaltphasen unterbrochen.

Key words: $\quad$ Loess, paleopedology, landscape formation, Lower Austria, Paudorf, Middle Pleistocene, micromorphology

Addresses of authors: T. Sprafke*, B. Terhorst, Institute of Geography and Geology, University of Würzburg, Am Hubland, D-97074 Würzburg, Germany.E-Mail: tobias.sprafke@uni-wuerzburg.de; birgit.terhorst@uni-wuerzburg.de; R. Peticzka, Institute of Geography and Regional Research, University of Vienna, Althanstrasse 14, A-1090 Wien, Austria. E-Mail: robert.peticzka@univie.ac.at; C. Thiel, Nordic Laboratory for Luminescence Dating, Department of Earth Sciences, Aarhus University, Risø DTU, Frederiksborgvej 399, 4000 Roskilde, Denmark; Centre for Nuclear Technologies, DTU Risø Campus, Frederiksborgvej 399, DK-4000 Roskilde, Denmark. E-Mail: chrth@risoe.dtu.dk., "corresponding author 


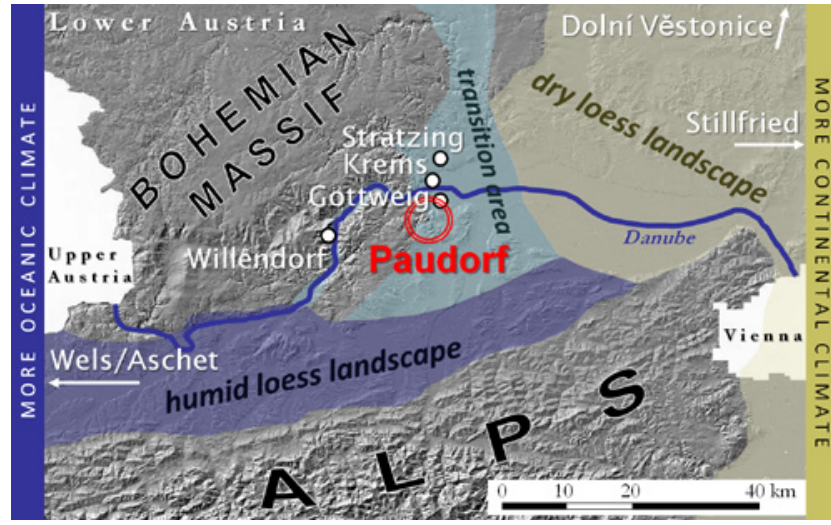

Fig. 1: Paudorf and other important loess-paleosol sequences in the loess landscapes of Lower Austria after FINK (1956). Base map: GEOinfo NÖ.

Abb. 1: Paudorf und weitere wichtige Löss-Paläoboden-Sequenzen in den österreichischen Lösslandschaften nach FINK (1956). Kartengrundlage: GEOinfo NÖ.

\section{Introduction}

Loess-paleosol sequences are the most suitable terrestrial archives to reconstruct landscape responses to Quaternary climate changes on regional to continental scale in the temperate latitudes with several $10^{3}$ to $10^{4}$ years resolution (cf. BRONGER 2003). For periods as far back as Marine Isotope Stage (MIS) 5 various types of records and dating methods already allow relatively detailed reconstructions. In contrast, earlier landscape responses to past climate changes remain a subject of controversial discussions (e.g. TERHORST 2007; Preusser \& Fiebig 2009; Scholger \& Terhorst 2011), despite the accurate record of global temperature fluctuations from deep-sea oxygen isotope measurements (LISIECKI $\mho$ RAYMO 2005).

Reconstructions of past landscapes and climates require data from numerous localities and regions respectively, as well as reliable dating methods. For Europe, on the mentioned time scales of climate change, posterior to the Matuyama-Brunhes boundary, the most complete terrestrial archives exist in the plateau loess sediments of the Middle Danube Basin that are relatively well suited for correlations and quantitative research (BRONGER 1970, 1976, 2003; MARKOvic et al. 2006, 2009, 2011). Geographically, Lower Austria has a key position related to paleoclimatology, between Central Europe, influenced by more marine climate, and the more continental Eastern Europe. Most thick loess deposits in Lower Austria are found on slopes in leeward positions and therefore are often influenced by hillslope processes. Due to the greater complexity of these archives, straight forward correlations and the application of quantitative methods is hampered. The need for detailed assessment of the processes leading to the formation of the archives is evident, and will give at least qualitative to semi-quantitative information about past environmental conditions.

The northeast of Lower Austria is sheltered from the moisture of the Atlantic and the Mediterranean Sea by the Bohemian Massif in the west and the Alps in the south respectively, which results in an increased continentality. Holocene Chernozems versus Eemian Bw horizons in the area give evidence for a pronounced sensitivity to climate change. This is especially true for the "transition area" around the city of
Krems a.d. Donau between the "dry loess landscape" further east and the "humid loess landscape" west of the Bohemian Massif (cf. FInK 1956; Fig. 1). The "humid loess landscape" has a present mean annual precipitation around 700-900 $\mathrm{mm}$ and exhibits mostly soils of the Cambisol-Luvisol group, whereas the "dry loess landscape" has an annual precipitation around 500-550 $\mathrm{mm}$ and exhibits mostly soils of the Phaeozem-Chernozem group.

Despite some general spatial relationships, a regional stratigraphy, as attempted by BAYER $(1909,1927)$, GÖTZINGER (1936), LAIS (1951), BRANDTNER (1954) and most importantly FINK $(1954,1956,1960,1961,1976)$, has never been satisfactorily established due to a lack of suitable dating techniques as well as sequences that are polygenetic and contain gaps.

Paleomagnetic studies were carried out in the 1970s to establish stratigraphical models in the longest records of glacial-interglacial cycles of Krems Schießstätte (shooting range) and Stranzendorf (FInK 1976; FINK \& KuKLA 1977; VERGINIS 1993). More recently, loess research in Lower Austria has mainly dealt with luminescence dating of some previously studied sequences (ZöLLER et al. 1994; Noll et al. 1994; Terhorst et al. 2011; Thiel et al. 2011a; Thiel et al. 2011b). Research is also focused on high resolution records of MIS 2 to 3, most notable for Paleolithic findings, such as at Stratzing, Willendorf and Krems-Wachtberg (NEUGEBAUER-MARESCH 1993; HAESAERTS et al. 1996; EINWÖGERER et al. 2006; Thiel et al. 2011a). Aside from that only a small number of studies have tried to unravel the very complex Middle and Late Pleistocene paleoenvironmental archives (Kovanda et al. 1995; PeticzKa et al. 2009).

One important loess-paleosol sequence in this area is the renowned section of Paudorf, first described by GöTzINGER (1936). In this sequence, a pedocomplex that can be correlated to MIS 5, is exposed in the upper part (ZöLLER et al. 1994; Thiel et al. 2011b). On the basis of detailed paleopedological and sedimentological data this study aims to understand the complex pedogenetical and geomorphological processes in the interplay of local influences and climatically induced environmental changes.

\section{The locus typicus Paudorf}

Paudorf (257 $\mathrm{m}$ a.s.l.) is situated in the hilly transition area between the Bohemian Massif and the Molasse Basin to the east, $7 \mathrm{~km}$ south of the city of Krems (203 $\mathrm{m}$ a.s.l.). The surrounding hills consist predominantly of granulite (mostly quartz, feldspar, garnet and some mica) with sporadic lenses of ultrabasic rock (GEOlogische BundesAnstalt 2002; MAtura 2006). At the foot of the Waxberg (500 m a.s.l.), northwest of the village of Paudorf, the $>12 \mathrm{~m}$ thick loess-sequence is exposed at $265-270 \mathrm{~m}$ a.s.l. in an approximately 70 $\mathrm{m}$ long outcrop facing SE and belonging to a former loampit. In Figure 2, a sketch of the outcrop with the two prominent pedocomplexes is presented. The thickness of the loess sediments between the $1 \mathrm{~m}$ thick upper and the $>2 \mathrm{~m}$ thick lower pedocomplex is increasing to the right hand side (NE).

Based on similarities to the famous paleosol of the nearby Göttweig/Furth outcrop, GöTzINGER (1936) correlated the pedocomplex in the lower part of the Paudorf sequence with the "Göttweiger Verlehmungszone" sensu BAYER (1927). Following the German terminology, "Verleh- 


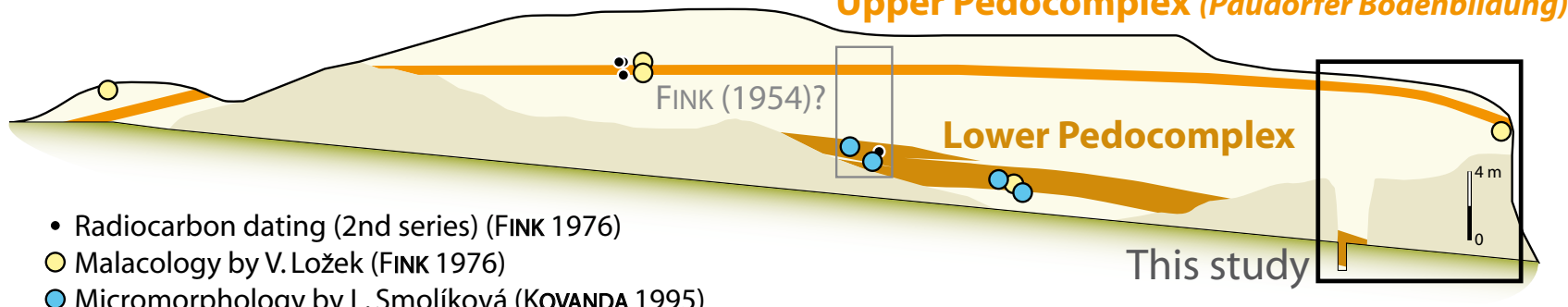

O Micromorphology by L. Smolíková (KovANDA 1995)

Fig. 2: Overview of the outcrop and former studies (black square: see Fig. 3). Redrawn and modified from FINK 1976, Fig. 31. Abb. 2: Überblick über den Aufschluss und frühere Arbeiten (Schwarzes Quadrat: diese Arbeit, vgl. Abb. 3). FINK 1976, Abb. 31, neu gezeichnet und verändert.

mung" is the pedogenic process of clay neo-formation, resulting in a Bv horizon (cf. AD-Hoc-ARBEITSGRUPPE BoDEN 2005; Bw horizon after IUSS WORKING Group WRB 2006). For the upper pedocomplex, GöTZINGER (1936) introduced the term "Paudorfer Leimenzone/Verlehmungszone", later named "Paudorfer Bodenbildung" (Paudorf soil/paleosol) by BRANDTNER (1954) and Fink (1956). It has to be noted that the term "Paudorfer Bodenbildung" sometimes refers only to the prominent $0.3-0.4 \mathrm{~m}$ thick, speckled part of the $\sim 1.0 \mathrm{~m}$ thick pedocomplex (e.g. in Fink 1956).

Depending on the interpretation, either both pedocomplexes in the Paudorf sequence (LAIS 1951; BRANDTNER 1954, 1956) or at least the upper one (GöTZINGER 1936; FINK 1954, 1956) were seen to represent an interstadial of the Würm glaciation sensu PENCK \& BRÜCKNER 1909. Two series of radiocarbon dating (FINK 1961, 1976) supported the idea of Paudorf being the locus typicus for a pronounced interstadial of the last glacial, the "Paudorf (Interstadial)". In the 1960s and early 1970 s this term was widely accepted and used in loess research. Interglacial mollusk assemblages in the "Paudorfer Bodenbildung”, identified by V. Ložek (FINK 1976), and the revised stratigraphy by Fink (1976), could not prevent the term "Paudorf" still being present in neighboring sciences such as paleontology and archeology as interstadial around 30 ka (PAZONyi 2004; ANGHeLINU \& NiţĂ 2012).

Thermoluminescence (TL) ages presented in NolL et al.

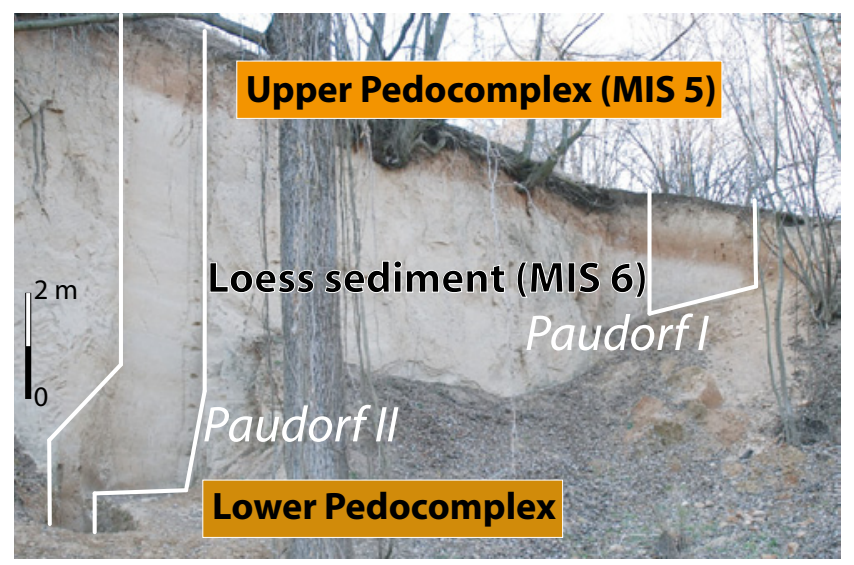

Fig. 3: Overview of the studied profiles. The lowest parts of Paudorf II in the small pit on the left hand side (cf. Fig. 4-3a) are not visible here.

Abb. 3: Überblick über die untersuchten Profile. Der untere Abschnitt von Paudorf II in der Schürfgrube linker Hand (vgl. Abb. 4-3a) ist hier nicht vollständig sichtbar.
(1994) support the ideas of GöTzINGER (1936), whereas the TL dating results, in combination with amino acid chronology by ZöLLER et al. (1994), lead to a correlation of the "Paudorfer Bodenbildung" with MIS 5. Recently published post-IR infra-red optically stimulated luminescence datings (post-IR IRSL; cf. Thiel et al. 2011a) reveal ages between 106 \pm 12 and $159 \pm 20$ ka for the upper pedocomplex (THIEL et al., 2011b). These results confirm its formation during the last interglacial and the early glacial, because this new dating technique is not prone to any significant over- or underestimation at this age range (BUYLAERT et al., 2012). In the loess sediment below the pedocomplex, ages of $187 \pm 12$ and $189 \pm$ $16 \mathrm{ka}$ do not suppose any major hiatus in the upper $7.5 \mathrm{~m}$ of the sequence. Consequently, it is most likely that most parts of the profile are of Middle Pleistocene age.

\section{Methods}

In contrast to FINK $(1954,1976)$, the studies were conducted in the northeastern part of the outcrop, where the sequence of loess sediments between the two pedocomplexes is thicker, thus providing higher resolution. Here, the layers/horizons are dipping $10-15^{\circ}$ to the right hand side of the profile wall (NE). The two profiles presented in THIEL et al. (2011b), which were based on the studies of PETiczka et al. (2009) were further extended. One composite Paudorf sequence is presented in this study, which involves the neighboring profiles Paudorf I (2.5 m thick, upper pedocomplex and surrounding loess sediments) and Paudorf II (11.8 m thick, sequence below upper pedocomplex). The presence of the upper pedocomplex in both profiles allows the correlation of the two sequences. The setting is illustrated in Figure 3. High resolution sampling of $1 \mathrm{dm}^{3}$-blocks in $1 \mathrm{dm}$ intervals (cf. Continuous Column Sampling [CCS] by AnToINe et al. 2009) was carried out in both profiles, including some overlap in the upper pedocomplex. The color/carbonate measurements of the statistically taken samples enhance the consistency of the units and subunits clarified during the field survey. The positions of the samples for grain size analyses are indicated in Figure 6.

\subsection{Field survey}

The description of the pedological and sedimentological parameters is based on the German Mapping Key for Soils (AD-Hoc-ArbeitsGruppe Boden 2005) and was adapted to 
the World Reference Base for soil resources (IUSS WORKING Group WRB 2006). We note that these guidelines are made for modern soils, and that many horizons exhibit features that were formed under environmental conditions different from today. Bleached horizons in loess sediment are commonly explained by iron reduction in water saturated substrates above the permafrost table in times without extreme eolian input and redeposition. These "Naßböden" sensu SchöNHALs et al. (1964) are close to Cryosols (Reductaquic) after WRB (IUSS WorkING GROUP WRB 2006) if assumed environmental conditions during pedogenesis are taken into account.

\subsection{Laboratory analyses: texture, carbonate content, color}

After homogenizing the samples, representative fractions $(\sim 400 \mathrm{~g})$ were dried for two days at $45{ }^{\circ} \mathrm{C}$. Half of the samples were dry-sieved to $<2000 \mu \mathrm{m}$ to produce fine earth which was used for all analyses except the sieving procedure. Water contents were estimated gravimetrically, parallel to weighing out. 30-40 g of each corresponding sample were oven-dried (two days, $105{ }^{\circ} \mathrm{C}$ ) and the results considered in weight-based calculations.

$100 \mathrm{~g}$ of each bulk sample were without chemical pretreatment suspended in water and wet sieved for $40 \mathrm{~min}$ in a Retsch AS200 basic sieving apparatus $(2000 / 630 / 200 / 63 / 40 \mu \mathrm{m})$. The fractions were oven-dried and weighted. The remaining suspension $<40 \mu \mathrm{m}$ was discarded and its weight-percentage calculated. To measure the fractions of this suspension, of each fine earth sample 10-15 g (depending on the content of fractions $<40 \mu \mathrm{m}$ ) were without further pretreatment wet-sieved to $<40 \mu \mathrm{m}$. Treated with $\mathrm{Na}_{4} \mathrm{P}_{2} \mathrm{O}_{7}{ }^{*} 10 \mathrm{H}_{2} \mathrm{O}$ in solution, the fractions of the suspension $<40 \mu \mathrm{m}(40 / 20 / 6.3 / 2$ $\mu \mathrm{m})$ were measured as weight-percent using a Micromeritics Sedigraph III 5120 by means of X-rays during sedimentation; the principle is based on Stokes' Law. Gravel (> 2000) is calculated in weight-percent of the whole sample. Fractions $<2000 \mu \mathrm{m}$ are calculated in weight percent of total fine earth.

Following DIN ISO 10693 1-2 g of each air-dried fine earth sample were taken for gas-volumetric estimation of carbonate content of the sample after reaction with $10 \mathrm{ml}$ of $10 \% \mathrm{HCl}$ by means of Scheibler Apparatus.

The oven-dry fine earth used for gravimetric estimation of water content was taken for color measurement, using the Spectrophotometer SPH 850. Before the lens was placed on the samples, the aggregates were thoroughly pounded to prevent shadow effects. The resulting color values $(10 \mathrm{~nm}$ steps from 400 to $700 \mathrm{~nm}$ ) are calculated by dividing the ten highest summated intensities $(700-600 \mathrm{~nm})$ by the ten lowest values $(500-400 \mathrm{~nm})$. The values were normalized to the color of the most loess-like part in P3 (sample in $2.25 \mathrm{~m}$ depth). Values $>1.0$ are "warmer" (brownish, reddish) colors, representing decalcification, oxidation as well as humification, while values $<1.0$ are "colder" colors (bluish, whitish), resulting from iron reduction and carbonate illuviation. A single one-dimensional parameter adequately quantifying qualitative field perception was favored in this study of a polygenetic sequence over several published color proxies that seek for quantification of pedogenetic intensities (e.g. VISCARRA RosSEL 2006; BÁBEK et al. 2011).

\subsection{Microscopic studies}

Microscopic studies have been carried out in order to obtain further qualitative insight into the complex genesis of the sequence. From several samples each of the five fractions obtained by sieving was studied under binocular microscope to assess their specific composition. Thin sections of the two pedocomplexes have been studied qualitatively under a Leitz DMRB polarizing microscope to principally understand their polygenetical formation. Detailed micromorphological studies are the subject of ongoing studies. The thin sections were produced from resin-impregnated undisturbed block samples.

\section{Results \\ 4.1 Field survey}

Overview and detailed photographs of the outcrop are presented in Figure 4. Down to a depth of $11.80 \mathrm{~m}$, the standard Paudorf sequence is differentiated into eight units, with units $\mathrm{P} 2$ and $\mathrm{P} 7$ covering the two prominent pedocomplexes. Below we highlight the main characteristics of the sequence. For field parameters, soil horizon designations and further descriptions see Figures 5 and 6.

In general, the outcrop shows a stable, wall-forming, differentiated, mostly yellowish-grey substrate dominated by silt-sized particles and a considerable percentage of sand. Both, the particles of the loess-like sediment (P1, P3-6, P8) and of the pedocomplexes (P2 and P7) form blocky to subpolyhedral aggregates. Carbonate is abundant in all units, except the lower pedocomplex (P7).Each layer/horizon bears granulite fragments of up to gravel size. Several thin bands, rich in gravel and coarse sand, are visible. In the prominent brownish to reddish pedocomplexes rock fragments as large as several $\mathrm{cm}$ in length are present.

The top of the profile exhibits an approximately $0.5 \mathrm{~m}$ thick disturbed Cambisol (not shown in the standardized profile).

P1 has yellowish gray loess-color and loess-structure, but contains more fine sand than typical loess (cf. PyE \& SHERWIN 1999). No macroscopical secondary carbonates are present. The boundary to $\mathrm{P} 2$, the upper pedocomplex, is gradual (Fig. 4-1a). Subunit P2a is darker and contains more clay and pseudomycelia. P2b leads into a 0.3-0.4 m thick reddish-brown horizon $(\mathrm{P} 2 \mathrm{c})$; this unit has a relatively regular pattern of brown interconnected irregularly shaped speckles of up to $2 \mathrm{~cm}$ in size and is the classical, "Paudorfer Bodenbildung" after Fink (1956) (Fig. 4-1b). The surfaces of the crumbly and porous blocks to sub-polyhedrons are free of clay coatings (Fig. 4-1c). A striking feature is the presence of several granulite cobbles (Fig. 4-1d). In addition to numerous crotovinas, the lower boundary of P2c and the entire darkgrayish subunit $\mathrm{P} 2 \mathrm{~d}$ are distorted in a complex pattern. The irregular boundaries resemble cryogenic pockets and wedges slightly deformed by hillslope processes.

P3 to P6 are the sequence of loess sediments between the two prominent pedocomplexes (Fig. 4-2a). Evidence for eolian sedimentation, redeposition and weak pedogenesis can be found in all units. P3 is the least differentiated, most loess-like substrate, with very weak signs of soil formation and colluvial processes. $\mathrm{P} 4$ is more heterogeneous, striat- 

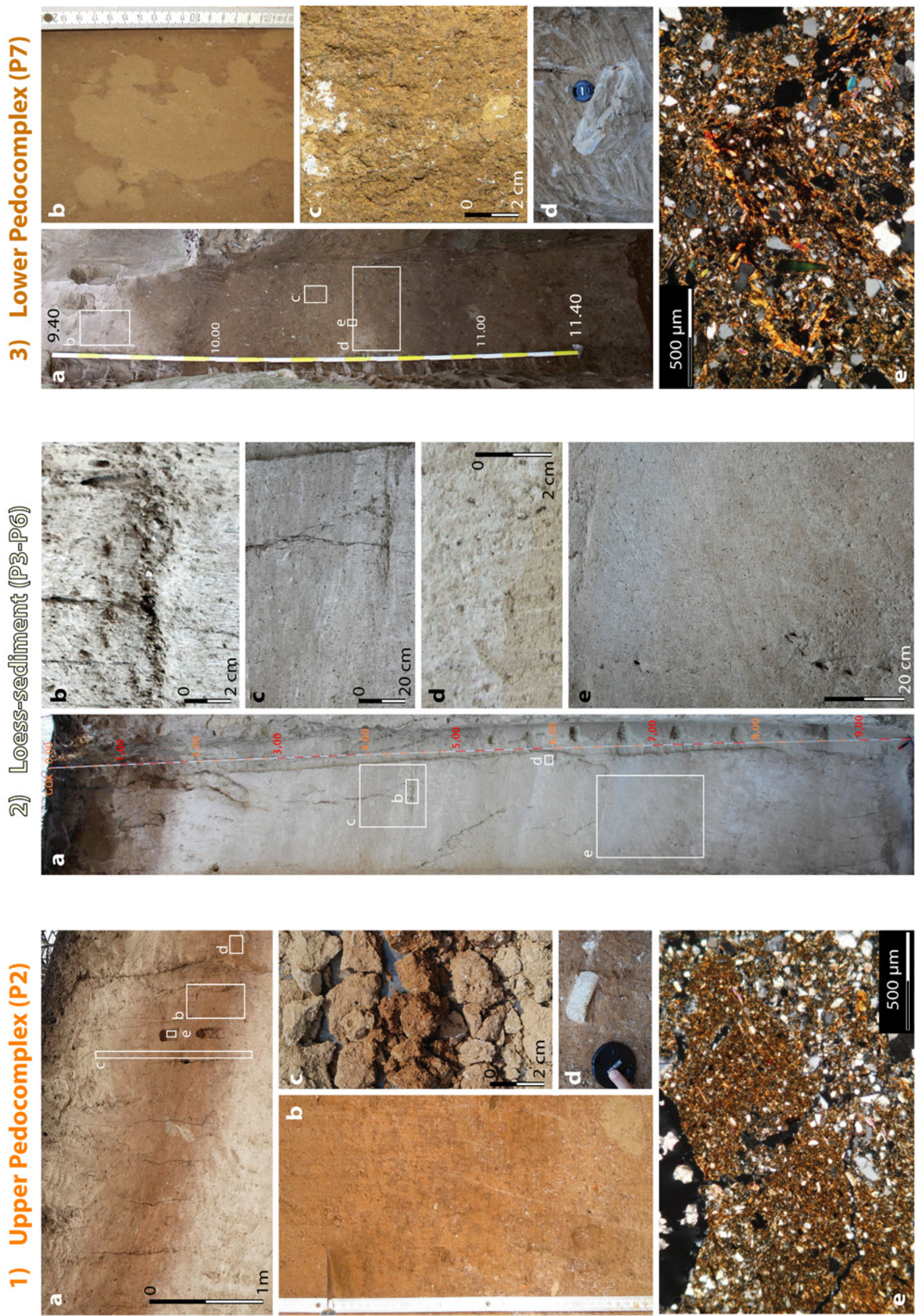

Fig. 4: Panel of macroscopic and microscopic images of characteristic parts of the Paudorf sequence. Rectangles in images 1a, 2a, 3a indicate stratigraphic position of detailed images $b-d$.

Abb. 4: Zusammenstellung makro- und mikroskopischer Bilder charakteristischer Abschnitte der Sequenz Paudorf. Rechtecke in den Überblicksfotos 1a, 2a, 3 a zeigen die stratigraphische Position der Detailbilder b-e. 
ed and contains more gravel, partly in distinct bands (Fig. 4-2b). Redeposition features can be seen clearly. A considerable amount of carbonate and silt, as well as the presence of bleached horizons, show that eolian sedimentation occurred and alternated with weak pedogenesis (Fig. 4-2c). The three Cryosols (Reductaquic) of P5 indicate clearly pedogenesis (Fig. 4-2d); especially the upper (P5a) and the lower Cryosol (P5e) are well pronounced. P6 differs considerably from the loess sediments, as it is significantly enriched in sand, has lower carbonate content and a different hue. P6b is a brownish horizon with irregular boundaries to the adjacent horizons. Striations penetrating P6a in the opposite direction to the inclination of the horizon boundary are visible (Fig. 4-2e). Further, the brownish horizon seems to be disturbed internally. Around the lower boundary and slightly below (P6c), the highest sand contents of the entire sequence are found. Sharply defined areas of darker substrate resemble crotovina, root channels or a cryogenic structure. The color of these domains is comparable to the color of P6b.

P7 exhibits the $2.8 \mathrm{~m}$ thick lower pedocomplex and the transitional horizons above (Fig. 4-3a). In a continuous change of substrate from P6 to P7, a 10-20 cm thick layer rich in granulite gravel up to $2 \mathrm{~cm}$ in size has been chosen as the boundary (P7a). In general, P7 is carbonate free, more reddish-brown in the central subunits $(\mathrm{P} 7 \mathrm{c}-\mathrm{e})$ and more blackish-brown in the surrounding subunits. In P7b unevenly shaped, sharply defined lighter brown mottles are visible (Fig. 4-3b). The staining areas are bigger, but fewer, and are less regularly formed and arranged than the speckles in P2. The subunits P7c and P7e are more consolidated and the aggregates exhibit weak clay coatings (Fig. 4-3c). The intercalated P7d contains higher amounts of granulite and charcoal fragments. P7f has higher silt and less sand content, and lighter color. Pieces of granulite rock are present in this horizon (Fig. 4-3d). P7g consists of dark humic loam with areas of weak staining and crotovina, underlain by an inhomogeneous light brown horizon. P7i covers the grayish $10-20 \mathrm{~cm}$ thick transition horizon of P7 to P8, characterized by a dense network of pseudomycelia. P8 is the basal layer of the exposed profile, and consists of grayish, carbonaterich sandy loess.

\subsection{Laboratory results 4.2.1 Texture}

The rare rock fragments in P2 and P7 were noticed in the field, but were not taken during sampling. For results of texture analyses see Figure 6 and Table 1 . Sieving revealed that without exception, gravel $(\mathrm{G}$, grain size $>2000 \mu \mathrm{m})$ is present in every sample with an average value of $1.4 \%$. Values exceeding $2 \%$ are mainly associated with gravel bands enclosed in the samples (e.g. P4c-d and P7a-b).

In general, the sand $(\mathrm{S})$ content in fine earth ranges from $20-30 \%$. In $\mathrm{P} 5$ and $\mathrm{P} 7 \mathrm{a}-\mathrm{e}$ sand content is around $30 \%$ and in parts of $\mathrm{P} 6$ contents even exceed $40 \%$. In $\mathrm{P} 4$ and P5, the bleached horizons (P4c-d and P5a,c,e) have significantly lower sand content than the neighboring layers. The overall minima are present in $\mathrm{P} 2$ and $\mathrm{P} 3$, especially near their boundary. In general, fine sand (fS) is the dominating fraction with bulk contents between $10-25 \%$; its absolute content is responsible for variations in the overall sand con- tent. Coarse sand (gS) follows this trend only marginally and is to a certain extent also independent of gravel variations. Medium sand $(\mathrm{mS})$ ratios lie between those of coarse and fine sand.

On average, silt (U) makes up 50-60\% of the fine earth. In $\mathrm{P} 1-2 \mathrm{a}, \mathrm{P} 3$ and $\mathrm{P} 4 \mathrm{c}-\mathrm{d}$ silt contents are higher, in the more sandy units P6 and P7 lower, sometimes as low as $40 \%$ (P6b-c). Silt contents of the bleached horizons P5a,c,e are $\sim 5 \%$ higher than in P5b and $\mathrm{d}$. Bulk coarse $(\mathrm{gU})$ and medium silt $(\mathrm{mS})$ contents are in general similar in both absolute contents and changes throughout the profile, with the first reaching not more than $30 \%$ and the latter not more than $25 \%$. As fine silt (fS) varies only slightly around $14 \%$ throughout the profile, the changes in silt content are mainly reflected by the two coarser silt fractions. Fine silt shows an increase in the pedocomplexes (P2 and P7). In the sand rich $\mathrm{P} 6$, the three silt fractions have similar contents. It is interesting to note that the transition zone between P2 and P3 (enriched in secondary carbonate) exhibits relatively low bulk silt contents, where fine silt has a relative maximum and clay its absolute maximum.

Bulk clay $(\mathrm{T})$ contents exceed $15 \%$ in each fine earth sample. In the loess sediment units P3 to P6, the values vary around $20 \%$ with no clear trend. In the pedocomplexes (P2 and P7), clay contents reach more than $25 \%$. In general, relative clay maxima are present at the lower boundaries of the two pedocomplexes. Highest clay contents are present at the lower boundary of P2 and in the central horizons of P7. In the uppermost and lowermost units of loess-like sediment (P1 and P8) the clay contents differ strongly (16.6 and 25.2\%, respectively).

\subsubsection{Carbonate content and color}

The results of carbonate and color analyses are shown in Figure 6 and Table 1. Carbonate content is significantly lower in the pedocomplexes ( $\mathrm{P} 2$ and $\mathrm{P} 7)$ than in all other units. In contrast, the underlying units (P3 and $\mathrm{P} 8$ ) both exhibit strongly enhanced carbonate contents. The upper four units are in general richer in carbonate than the lowest three (more sandy) units. P5 exhibits intermediate values. The lower pedocomplex is almost completely decalcified whereas the upper pedocomplex has 6-7\% carbonate. P6b, the brownish colored horizon above the lower pedocomplex has $>6 \%$ less carbonate content than the over- and underlying units.

Color values support the field observations in a more sensitive and quantitative way. P2 and P7 show much more "warmer" coloring, with P7c-d exhibiting slightly higher intensities than P2c. P6 is also more intensely colored than the more loess-like units. The minima are present in the bleached horizons (P5a,c,e and $\mathrm{P} 4 \mathrm{~d}$ ) and in the carbonate illuvial horizons $\mathrm{P} 3 \mathrm{a}$ and $\mathrm{P} 8$.

Some interesting relation is visible by direct comparison of the relative maxima of carbonate and color value. Clearly, the pedocomplexes exhibit strong coloring and low carbonate contents, in connection with high carbonate values below. But this pattern is also traceable on a smaller scale: Around P $3 \mathrm{~b}$ and the boundary of P3d-4 a, in P4b and very clear in P6b and below, we detect higher color values connected with lower carbonate values and carbonate enrichment below. 


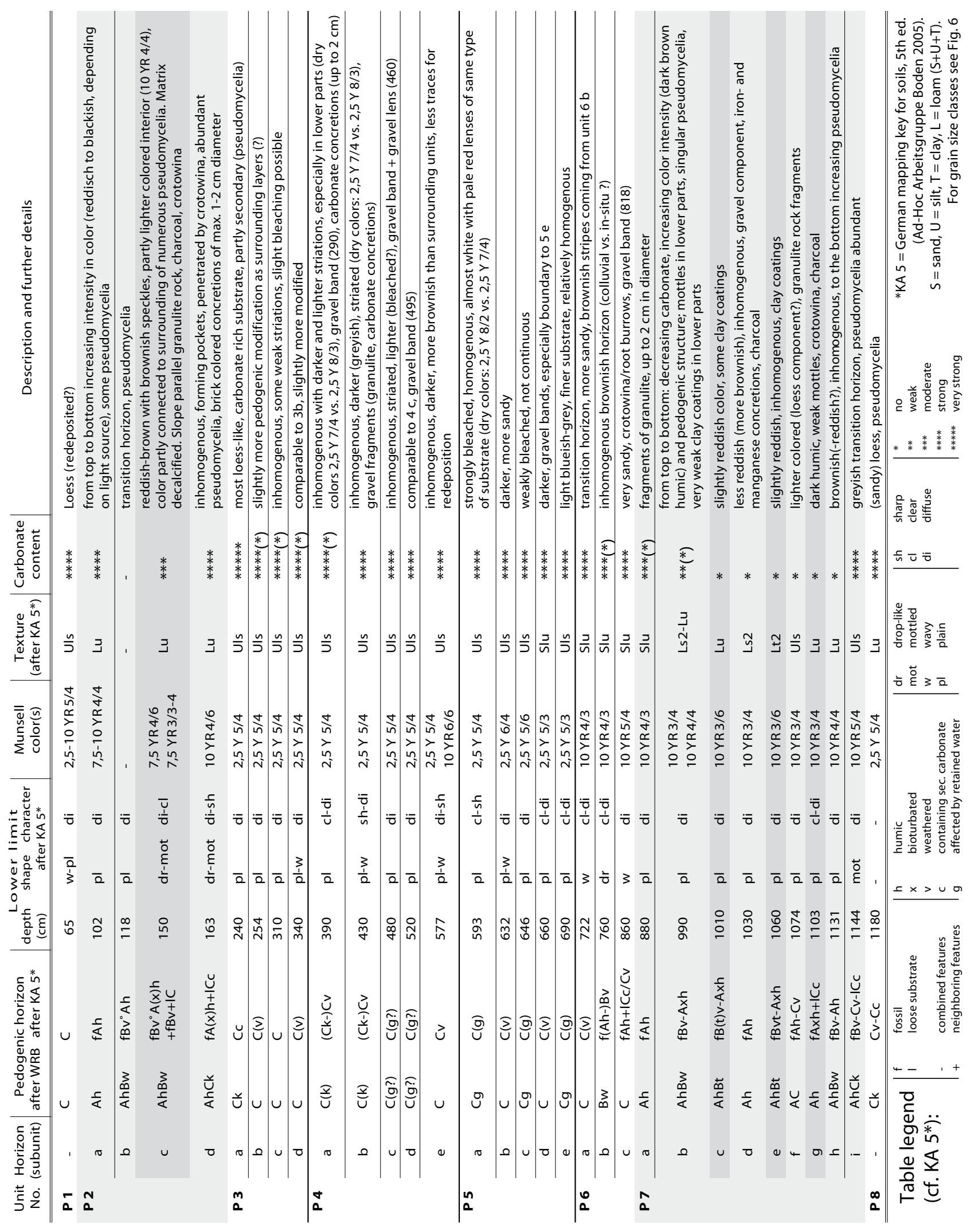

Fig. 5: Field description of the Paudorf sequence (stratigraphy sketch in Fig. 6)

Abb. 5: Geländedaten der Löss-Paläoboden-Sequenz Paudorf (Profilskizze in Abb. 6)

\subsection{Microscopic studies}

A regular pattern of the petrographical composition of the different fractions from the sieving (for classes cf. Fig. 6) was identified under binoculars. Gravel consists mainly of small angular to subangular rock particles bearing quartz, feldspar, garnet and other unidentified components. The composition and structure is identical to the local granulite. The surfaces of the fragments are partly oxidized and thus have yellowish to orange pigmentation. Coarse sand has a comparable com- 
position. In the medium sand fraction, granulitic material is successively replaced by aggregates of feldspar, quartz and pale garnet without darker accessories. The major portion of the $40-200 \mu \mathrm{m}$ fractions consists of unoxidized particles of disintegrated granulite. To a certain degree in the fine sand, and most obvious in the $40-63 \mu \mathrm{m}$ fraction, the petrographic composition shows greatest variety.

As no pretreatment with hydrochloric acid has been carried out before grain size analysis, secondary carbonates typical for loess-paleosol sequences (cf. BARTA 2011) contribute to the sand and gravel fractions. Carbonate concretions of 1-2 cm in size ("loess dolls") were found in P4a-b (cf. Fig. 5). Ochre colored, rough, branch shaped fragments of up to $3 \mathrm{~mm}$ in length were found in the sieves that are result of carbonate cementing (hypocoating) of pore wall substrates (mostly silt) in former root channels. Plain white calcified root cells (CRC) of $0.2-1 \mathrm{~mm}$ size, were also present.

The above mentioned patterns are also visible in the thin sections studied under petrographic microscopes, for example in the section of $\mathrm{P} 2 \mathrm{~b}$ (upper pedocomplex). Here, (sub-) angular coarse mineral grains of $>100 \mu \mathrm{m}$ diameter are predominantly local clastic material (granulite rock fragments or single granulite minerals). Furthermore, secondary carbonates (CRC, mollusk shell fragments, crystallized earthworm cast) and manganese nodules can have sand size. However, the dominant fractions in the sample are silt to clay sized. It consists of a broad spectrum of minerals typical for loess (quartz, feldspar, pyroxene, amphibole, mica, primary carbonates, clay minerals), secondary (pedogenic) minerals (clay minerals, iron- and manganese oxides), including secondary carbonates (lublinite, calcitic hypocoatings). These observations are of importance with respect to the results of texture analysis.

In the upper pedocomplex, minerals are only slightly altered. Micas for example are weakly oxidized. Clay coatings are not present, and only some domains of oriented clay are traceable; in many parts the structure is granular. Fragments of more intensely colored and more clay rich substrate containing less or no carbonate are present (Fig. 4-1e). Overall the substrate is quite heterogeneous.

Apart from a higher sand content, the composition of the groundmass of the lower pedocomplex is comparable. The thin section of P7e is darker pigmented than the sections of the upper pedocomplex and contains only very few secondary carbonate (micrite). The sample contains more clay in the groundmass as well as reddish-brown colored deformed clay coatings (Fig. 4-3e). Some areas of granular structure are also present in this horizon. CRC are only present in the sample of P7b, which exhibits more granular structure.

\section{Discussion}

In the morphological setting at the foot of the Waxberg hill, slope processes contribute to the genesis of the sequence. This is best reflected in the ubiquitous presence of gravel that does not fulfill expectations regarding an eolian sediment. Furthermore, none of the renowned paleosols described earlier is monogenetic (if we understand monogenetic as development over time under relatively homogenous climatic conditions). In the following the loess sediments between the two pedocomplexes will be discussed. First correlations with other records are attempted where chronological data are available. Afterwards the upper pedocomplex will be reviewed on the basis of existing and new data and assumptions on its genesis and its significance presented. The lower pedocomplex lacks a reliable chronological framework; therefore only preliminary concepts in respect to its genesis can be discussed.

\subsection{Loess sediment units [P1, P3-6, P8]}

P1, P3-6 and P8 are made up mostly of silt rich yellow-gray substrate that in some parts contains considerable amounts of coarser material of local origin. Next to eolian sedimentation, redepositional processes were common, creating an admixture of local materials. The substrate has blocky to subpolyhedral structure. Several paleosols that evidence phases of morphological stability were identified in the sequence between the two pedocomplexes.

A considerable part of the primary carbonate and silt rich material in P1, P3-6 and P8 can be attributed to eolian input. The finer sand fractions with a broad petrographic/mineralogical spectrum are most likely also wind-blown deposits. Saltation and reptation in environments of sparse vegetation are possible processes for the admixture of the coarser clastic particles of local origin. The partly layered appearance of the substrate and the presence of gravel bands indicates colluvial processes. The pale yellow color and the character of aggregates - most likely due to cementation by carbonate and clay in cold steppe environments (PÉCSI \& RICHTER 1996) resemble typical loess of temperate latitudes. These nearsurface diagenetic processes and redeposition may have occurred with seasonal alternation and are thus to be classified as syngenetic on the studied time scales.

If loess is defined genetically as wind-blown dust (e.g. Pye \& SHerwin 1999), there is clearly no loess (sub)unit present in the Paudorf sequence. Following SMALLEy et al. (2011) input of eolian dust is the most crucial element for loess genesis; the eolian dust provides physiochemical conditions, which are of great importance for the subsequent specific processes that alter the deposit in situ. In Paudorf, mineral dust is only one component of a substrate that has structural similarity to loess. Structural development, equally important for the genesis, is supposed to have taken place in situ, in a cold steppe environment. All twelve descriptive criteria for an adequate description of loess attributed to Márton Pécsi, listed in SMALLEy et al. (2011) are fulfilled to a certain grade within P1, P3-6 and P8. An exception is the very sandy P6c in which the silt content is less than $40 \%$ and therefore too low for loess after this definition. Referring to section 3 of this list, which says that loess horizons are usually unstratified, the striated appearance, especially in P4, should be noted as unusual. In PÉSCI (1990) and PÉCSI $\mho$ RichteR (1996) criteria are slightly different but the conceptual idea is identical. Acknowledging the fundamental ideas of L.S. Berg (cf. SMALLEY et al. 2011), adjusted by PÉcsI (1990; PÉCsI \& RICHTER 1996), it is possible to classify this yellowish substrate with loess structure, which is dominated by silt particles as "loess". According to KocH $\mho \mathrm{NeU}-$ MEISTER (2005), most parts of the loess sediment in Paudorf correspond to be named solifluction sand-loess ("Solifluktions-Sandlöss"). 

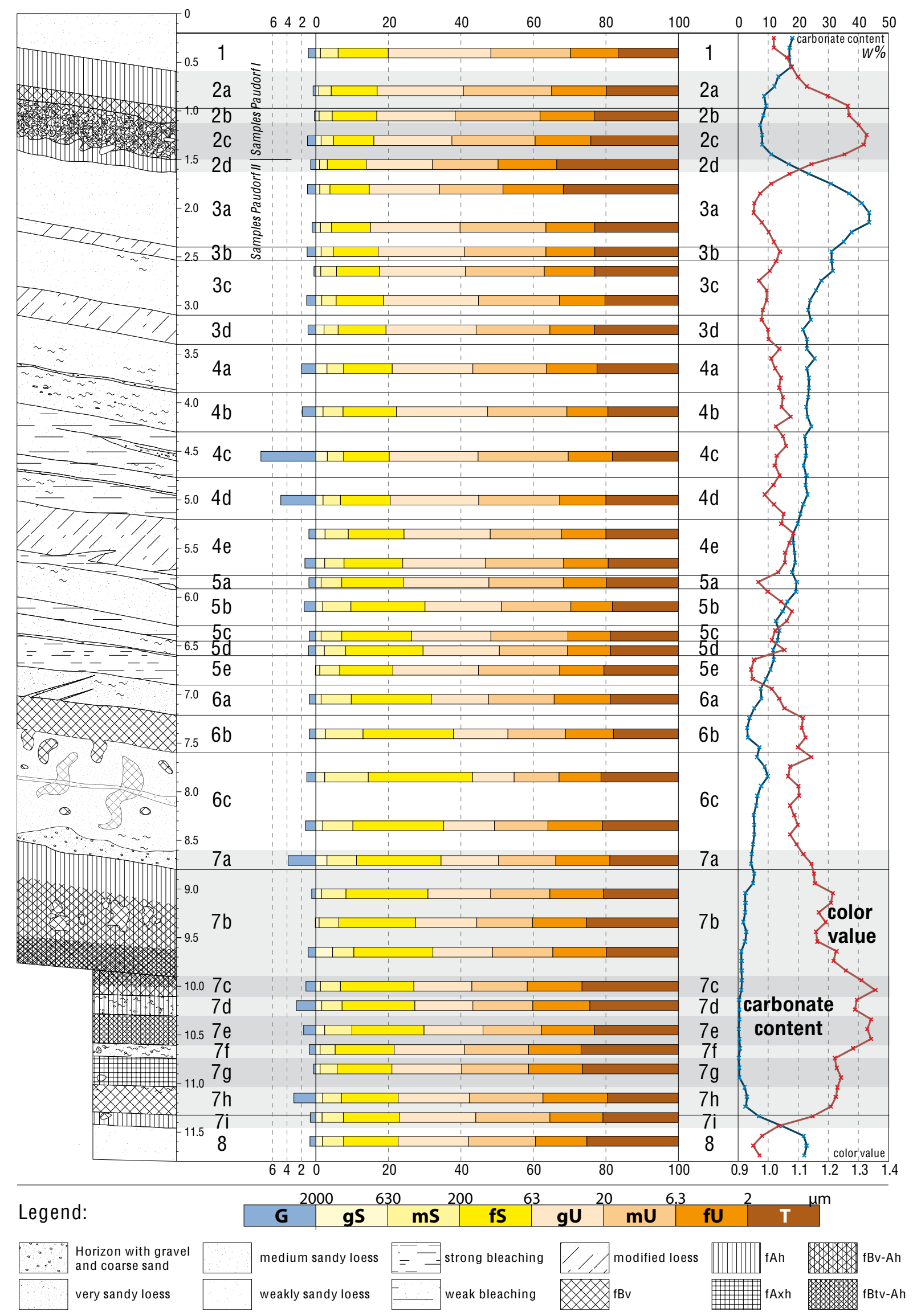

Fig. 6: Stratigraphy of the standard Paudorf sequence with texture analyses and high resolution carbonate contents and color values. The results are listed in Table 1. Grain size classes and names after KA 5 (AD-HOC-ARBEITSGRUPPE BODEN 2005).

Abb. 6: Stratigraphie der Standardsequenz Paudorf mit Ergebnissen der Korngrößenanalysen und Daten zu Carbonatgehalten und Farbwerten in hoher Auflösung. Die Ergebnisse sind in Tabelle 1 aufgelisted. Die Korngrößenklassen und -bezeichnungen folgen der KA 5 (AD-Hoc-ARBEITSGRUPPE BODEN 2005). 
Tab. 1: Results of laboratory analyses of texture, carbonate and color. For texture classes and names see Fig. 6. Color values and carbonate contents are calculated for the horizons of the texture analyses.

Tab. 1: Resultate der Laboranalysen von Korngrößen, Karbonatgehalten und Farbwerten. Die Korngrößenklassen und -bezeichnungen sind Abb. 6 zu entnehmen. Farbwerte und Karbonatgehalte sind auf die Horizonte der Korngrößenanalyse umgerechnet.

\begin{tabular}{|c|c|c|c|c|c|c|c|c|c|c|c|c|}
\hline $\begin{array}{l}\text { Sub- } \\
\text { unit }\end{array}$ & $\begin{array}{l}\text { G } \\
{[w \%]}\end{array}$ & $\begin{array}{l}g S \\
{[w \%]}\end{array}$ & $\begin{array}{l}\mathrm{mS} \\
{[\mathrm{w} \%]}\end{array}$ & $\begin{array}{l}\text { fS } \\
{[w \%]}\end{array}$ & $\begin{array}{l}\Sigma S \\
{[w \%]}\end{array}$ & $\begin{array}{l}g \mathrm{gU} \\
{[w \%]}\end{array}$ & $\begin{array}{l}\mathrm{mU} \\
{[\mathrm{w} \%]}\end{array}$ & $\begin{array}{l}\text { fU } \\
{[w \%]}\end{array}$ & $\begin{array}{l}\Sigma U \\
{[w \%]}\end{array}$ & $\begin{array}{l}T \\
{[w \%]}\end{array}$ & $\begin{array}{l}\text { Color } \\
\text { value }\end{array}$ & $\begin{array}{l}\text { Carbonate } \\
{[\mathrm{w} \%]}\end{array}$ \\
\hline P1 & 1.0 & 1.3 & 4.8 & 13.8 & 20.0 & 28.3 & 22.0 & 13.1 & 63.4 & 16.6 & 1.04 & 17.2 \\
\hline P2a & 0.4 & 0.8 & 3.5 & 12.6 & 16.9 & 23.8 & 24.3 & 15.1 & 63.2 & 19.9 & 1.16 & 10.4 \\
\hline $\mathrm{P} 2 \mathrm{~b}$ & 0.2 & 1.0 & 3.6 & 12.3 & 16.8 & 21.6 & 23.4 & 14.9 & \begin{tabular}{|l|}
59.9 \\
\end{tabular} & 23.3 & 1.27 & 8.4 \\
\hline P2C & 1.2 & 1.5 & 3.4 & 11.1 & 16.0 & 21.5 & 22.9 & 15.3 & 59.8 & 24.2 & 1.32 & 8.0 \\
\hline P2d & 0.7 & 1.0 & 2.2 & 10.8 & 14.0 & 18.2 & 18.1 & 16.2 & 52.5 & 33.5 & 1.14 & 16.9 \\
\hline P3a1 & 1.2 & 1.2 & 2.7 & 10.9 & 14.8 & 19.3 & 17.6 & 16.6 & 53.5 & 31.7 & 0.99 & 34.0 \\
\hline Р3а2 & 0.5 & 1.3 & 3.0 & 10.7 & 15.1 & 24.7 & 23.7 & 13.4 & 61.8 & 23.1 & 0.99 & 40.8 \\
\hline P3b & 1.2 & 1.4 & 3.4 & 12.3 & \begin{tabular}{|l|}
17.2 \\
\end{tabular} & 23.9 & 22.4 & 13.5 & 59.8 & 23.1 & 1.04 & 31.1 \\
\hline P3c1 & 0.3 & 1.4 & 4.3 & 11.8 & 17.6 & 23.7 & 21.8 & 13.9 & 59.3 & 23.1 & 1.01 & 31.6 \\
\hline Р3c2 & 1.3 & 1.7 & 3.9 & 13.0 & 18.7 & 26.2 & 22.4 & 12.6 & 61.1 & 20.2 & 1.00 & 24.0 \\
\hline P3d & 1.1 & 2.3 & 3.9 & 13.2 & 19.3 & 24.8 & 20.4 & 12.3 & 57.5 & 23.1 & 1.00 & 21.7 \\
\hline Р4а & 2.0 & 3.1 & 4.6 & 13.4 & 21.1 & 22.2 & 20.2 & 14.0 & 56.4 & 22.5 & 1.02 & 23.0 \\
\hline P4b & 1.9 & 2.1 & 5.5 & 14.8 & 22.3 & 25.1 & 21.9 & 11.3 & 58.2 & 19.5 & 1.06 & 22.9 \\
\hline P4c & 7.6 & 3.2 & 4.5 & 12.5 & 20.3 & 24.5 & 24.8 & 12.3 & 61.6 & 18.2 & 1.03 & 22.6 \\
\hline P4d & 4.8 & 2.1 & 4.7 & 13.7 & 20.6 & 24.4 & 22.4 & 12.7 & \begin{tabular}{|l|}
59.5 \\
\end{tabular} & 20.0 & 1.01 & 22.5 \\
\hline P4e1 & 1.0 & 2.6 & 6.4 & 15.4 & 24.4 & 23.7 & 19.7 & 12.3 & 55.6 & 20.0 & 1.08 & 18.4 \\
\hline P4е2 & 1.5 & 2.4 & 5.3 & 16.2 & 24.0 & 22.8 & 21.5 & 12.3 & 56.7 & 19.4 & 1.06 & 19.0 \\
\hline $\mathrm{P} 5 \mathrm{a}$ & 1.0 & 1.5 & 5.6 & 17.0 & 24.1 & 23.6 & 20.6 & 11.8 & \begin{tabular}{|l|}
56.0 \\
\end{tabular} & 19.9 & 0.97 & 19.6 \\
\hline P5b & 1.6 & 1.9 & 7.8 & 20.5 & 30.1 & 21.1 & 19.1 & 11.5 & 51.7 & 18.2 & 1.06 & 15.7 \\
\hline $\mathrm{P} 5 \mathrm{c}$ & 0.9 & 1.5 & 5.7 & 19.2 & 26.4 & 21.8 & 21.2 & 11.7 & 54.7 & 18.8 & 1.02 & 13.5 \\
\hline P5d & 1.0 & 2.4 & 5.9 & 21.3 & 29.6 & 21.0 & 18.9 & 11.8 & 51.7 & 18.7 & 1.05 & 11.8 \\
\hline $\mathrm{P} 5 \mathrm{e}$ & 0.1 & 1.2 & 5.5 & 14.6 & \begin{tabular}{|l|}
21.2 \\
\end{tabular} & 23.6 & 22.4 & 12.3 & \begin{tabular}{|l|}
58.2 \\
\end{tabular} & 20.5 & 0.94 & 10.8 \\
\hline P6a & 0.9 & 1.5 & 8.2 & 22.1 & 31.8 & 15.8 & 18.1 & 15.5 & 49.4 & 18.8 & 1.04 & 7.8 \\
\hline P6b & 0.9 & 2.8 & 10.3 & 24.9 & 38.0 & 15.0 & 15.9 & 13.2 & 44.1 & 17.9 & 1.12 & 3.2 \\
\hline P6c1 & 1.3 & 2.5 & 12.0 & 28.7 & 43.2 & 11.5 & 12.4 & 11.6 & 35.4 & 21.3 & 1.07 & 9.9 \\
\hline P6c2 & 1.5 & 1.9 & 8.4 & 25.0 & 35.3 & 14.0 & 14.8 & 15.1 & 43.8 & 20.9 & 1.10 & 5.5 \\
\hline P7a & 3.8 & 3.1 & 8.1 & 23.3 & 34.5 & 15.8 & 15.8 & 14.9 & 46.5 & 19.0 & 1.13 & 4.5 \\
\hline P7b1 & 0.6 & 1.6 & 6.8 & 22.6 & 31.0 & 17.2 & 16.4 & 14.7 & 48.3 & 20.7 & 1.22 & 2.5 \\
\hline P7b2 & 0.1 & 0.9 & 5.5 & 21.1 & 27.5 & 16.8 & 15.4 & 14.8 & 47.0 & 25.4 & 1.19 & 1.8 \\
\hline P7b3 & 1.1 & 4.7 & 5.9 & 21.7 & 32.3 & 16.5 & 16.7 & 14.7 & 47.8 & 20.0 & 1.23 & 1.1 \\
\hline P7c & 1.4 & 1.3 & 5.5 & 20.2 & \begin{tabular}{|l|}
27.0 \\
\end{tabular} & 16.0 & 15.2 & 15.1 & 46.4 & 26.6 & 1.33 & 1.2 \\
\hline P7d & 2.7 & 1.6 & 5.7 & 20.1 & 27.4 & 16.0 & 16.5 & 15.8 & 48.2 & 24.4 & 1.29 & 0.4 \\
\hline P7e & 1.7 & 2.5 & 7.5 & 19.8 & 29.8 & 16.3 & 16.1 & 14.6 & 47.0 & 23.2 & 1.33 & 0.3 \\
\hline P7f & 0.9 & 1.2 & 4.2 & 16.3 & 21.7 & 19.3 & 17.7 & 14.5 & 51.5 & 26.9 & 1.28 & 0.6 \\
\hline P7g & 0.3 & 1.2 & 4.7 & 15.1 & 21.0 & 19.3 & 18.4 & 14.8 & 52.5 & 26.5 & 1.23 & 0.5 \\
\hline P7h & 3.0 & 1.9 & 5.2 & 15.6 & 22.7 & 19.7 & 20.3 & 17.7 & 57.7 & 19.7 & 1.23 & 3.0 \\
\hline P7i & 0.8 & 1.7 & 5.9 & 15.5 & 23.1 & 21.0 & 20.4 & 14.7 & 56.1 & 20.8 & 1.15 & 7.0 \\
\hline P8 & 0.8 & 1.8 & 5.9 & 15.0 & 22.7 & 19.4 & 18.4 & 14.2 & 52.1 & 25.2 & 0.97 & 22.4 \\
\hline
\end{tabular}

Morphologically stable phases of slightly moister conditions with reduced sedimentation rates (cf. BIBUs 1974, ANTOINE et al. 2009) are documented by Cryosols. The higher silt and lower sand contents in the bleached horizons of P5 compared to the surrounding (sub)units appear significant. They can be attributed to cryogenic weathering, but also to ongoing dust input. Post IR-IRSL ages (ThIEL et al. 2011b) indicate that the major part of the sequence between the two pedocomplexes (P3-5) can be attributed to MIS 6. The formation of Cryosols in the penultimate glacial is reported for several locations from Western to Central Europe. For Belgium/Netherlands "tundrasols" are reported by Meijs (2002) in the "B-Loess". This correlates to the findings of BIBUS $(1974,2002)$, who names a sequence of six "Naßböden" (wet soils) in the "Jungriss" loess as "Bruchköbeler Böden" (Bibus 2002). These paleosols are labeled from base to top
B1 to B6. B1 and B3 are more pronounced (BIBUs 1974, 2002) and potentially correlate to the Cryosols P5a and P5e in Paudorf.

The genesis of $\mathrm{P} 6 \mathrm{~b}$, a brownish horizon with reduced carbonate content in the upper part of the sandy P6 remains unclear. It appears rather inhomogeneous and could be interpreted as soil sediment. A crotovina-like pattern below can be seen as evidence for morphologic stability in a warmer phase.

The relation between carbonate content and color described in 4.2 .2 could be interpreted by slight sedimentological changes. On the other hand it is possible that further phases of morphological stability were detected several times in the profile: Slight decalcification with an increase in coloring, in combination with calcification a few decimeters below, could be attributed to slight pedogenesis. 


\subsection{Upper pedocomplex [P2]}

The upper pedocomplex (P2) formed during MIS 5 (ZöLLER et al. 1994; Thiel et al. 2011b). The combination of its features points strongly to polygenesis: It is characterized by a reddish-brown color, partly in a speckled pattern, enhanced clay content and less carbonate compared to the loess sediments. However, primary carbonates can be detected. Clay coatings were not identified. Rock fragments that are oriented parallel to the inclination of the horizons and frost structures at the lower boundary are characteristic.

P2, the "Paudorfer Bodenbildung", is contrary to previous assumptions not a Bw or Bt horizon (BRANDTNER 1954; PETICZKA et al. 2009); neither it can be classified as an Ah horizon (SEMMEL 1968; Bronger 1976). V. Ložek (in FinK 1976) stated that the "Paudorfer Bodenbildung" is a complicated pedocomplex. However, no attempt was made to investigate the sequence in greater detail to reconstruct the processes leading to its formation. We assume the formation of a Chernozem in a redeposited Cambisol. During redepostion of the Cambisol, admixture of primary carbonate took place that was not leached during the development of the Chernozem.

\section{Stages of development}

The first step in the genesis of the pedocomplex after deposition of the parent material (loess sediment) is the development of a Cambisol. Passive and active reddish-brown pigmentation due to carbonate leaching and formation of iron oxides respectively lead to the formation of a Bw horizon. In general, rubified soils develop in ecosystems with a pronounced dry season. However, the reddish component can also be explained by reddening after burial (RETALLACK 2001). The carbonate maximum is found directly below P2, in P3a. This could evidence relatively shallow decalcification if the Cambisol was not too much eroded. It has to be noted in this context that the role of $\mathrm{P} 3 \mathrm{a}$ as uppermost loess-unit in the subdivision of the polygenetic loess-paleosol sequence is ambiguous. Being the $\mathrm{Ck}$-horizon of the Cambisol it could be assigned also as lowermost subunit of P2. Reddish pigmentation is as shallow decalcification in general common in environments with a seasonal precipitation.

Clay contents in P2 are enhanced; therefore the question of humidity resulting in hydrolytical weathering with clay neoformation is to be discussed. It is firsthand likely that the higher fine silt and clay content at the boundary of P2 and $\mathrm{P} 3$ is partly due to precipitation of microcrystalline calcite that is visible in thin sections. However, some chemical weathering resulting in clay neoformation likely took place, as decalcified clay-rich material was detected in the thin section (Fig. 4-1e). V. Ložek found mollusks (Aegopis verticillus [LAM], Pagodulina pagodula [DESM.], Cepaea vindobonensis [FÉR.]) at the lower boundary of the "Paudorfer Bodenbildung", which indicate humid interglacial conditions; even more humid than indicated by the Holocene fauna (in FINK 1976). Our results, however, give no evidence for pronounced humidity, which would most likely result in clay illuviation. To summarize the first phase in the genesis of the pedocomplex, the formation of a Cambisol, potentially in a temperate climate with seasonal precipitation is assumed.

Rock fragments as well as primary carbonate grains imply that the (probably decalcified) Cambisol was later trun- cated and reworked. During redepositon wind-blown dust with carbonate component was admixtured. At least one interval of periglacial conditions during this phase can be assumed; the rock fragments in $\mathrm{P} 2$ are oriented parallel to the inclination of the horizons, which is typical for solifluction, and the boundary to $\mathrm{P} 3$ is characterized by deformed wedges and pockets, which are most likely caused by cryogenic processes.

A dark pigmentation of $\mathrm{P} 2$, primary carbonate and a granular structure led SEMMEL (1968) and BRONGER (1976) to the conclusion that the "Paudorfer Bodenbildung" at the locus typicus is a fossilized Chernozem. In its upper part V. Ložek detected a Tridens-fauna that corresponds to early last glacial interstadial Chernozems (FINk 1976). This typical steppe soil is characterized by humification and bioturbation. Calcified root cells may be relics of the steppe environment. The speckles/mottles in humic horizons are likely caused by postpedogenetical humus degradation and are a common feature in early last glacial humic horizons (RoHDENBURG 1964).

Pedogenesis in the steppe environment was successively replaced by accumulation of eolian dust and fine sand, documented in the diffuse upper boundary of P2 and increasing silt contents in P1.

\section{Chronology and correlation}

The post-IR IRSL date of $106 \pm 12 \mathrm{ka}$ above the "Paudorfer Bodenbildung" published by THIEL et al. (2011b) indicates that pedogenesis during MIS $5 \mathrm{a}$ is not documented in Paudorf. On the contrary, ZöLLER et al. (1994) revealed TL-ages of $54 \pm 6$ ka from a comparable stratigraphical position.

On the base of these datings and our results, the Cambisol formation is attributed to MIS 5e (Eemian), the redepositon to the cold $5 \mathrm{~d}$ stage, and the early glacial interstadial Chernozem to MIS 5c[-a]. The processes found in P2 during Eemian and early last glacial can be correlated with standard MIS 5 pedocomplexes in Central Europe: The paleosol stack of Stillfried A, also named "Stillfrieder Komplex" exhibits a basal "Verlehmungszone" (Bw horizon) of a truncated Cambisol and three Ah horizons on top, separated by thin layers of loess sediment (FINK 1954; BRONGER 1976). In the German loess stratigraphy a comparable scheme exists. The fossil Ah horizons above the remaining Bt horizons of the truncated Eemian Luvisols are named Mosbacher Humuszonen (SchÖNHALs et al. 1964; SEMMEL 1968). A comparable pattern of MIS 5 paleosols is found in the Czech Republic, e.g. in Dolní Věstonice (Bronger 1976; Frechen et al. 1999; BÁBEK et al. 2011). In P2 of the Paudorf sequence, the paleosols of the classical MIS 5-complexes are found not superimposed but interlaced.

\section{Geographical significance}

Pedocomplexes comparable to P2 in Paudorf are present in the region, for example in the outcrops of Stiefern, Buchberg or Göttweig-Aigen (cf. FINK 1956, 1976). At the present state of research it is likely that P2 is a typical MIS 5-pedocomplex in the transition area of the Austrian loess landscapes after Fink (1956). P2, the classical "Paudorfer Bodenbildung", can be regarded as the missing link between the MIS 5-complexes of the "humid loess landscape" (Linzer Komplex: an Eemian fossil Bt horizon and early glacial soil sediment) and "dry loess landscape" (Stillfrieder Komplex), defined by Fink 
(1956). Although Fink (1961) presented time ranges and correlations that were revised at a later stage, we agree with his early assumption that the transition area is characterized both by pedogenesis of the "dry loess landscape" as well as intensive early glacial colluvial events, which are clearly documented in the profiles of the "humid loess landscape". In this context it should be mentioned that more recent studies have revealed that colluvial layers above Eemian paleosols in the "humid loess landscape" do not necessarily represent only the early glacial (MIS $5 \mathrm{~d}-5 \mathrm{a}$ ), but also younger stages up to MIS 3 (TERHORST et al. 2002).

In future, it has to be discussed, whether Paudorf will be again accepted as type locality, but now for the MIS 5-complex of the "transition area" in Austrian loess landscapes, and if yes, whether the term "Paudorfer Bodenbildung" should still be used or finally dismissed. It is not a monogenetic paleosol and it carries some historical burden in context of Quaternary stratigraphy.

From a broader paleoclimatological perspective, the presented findings appear promising, related to the question of Eemian (MIS 5e) paleoclimate in Central Europe. In Paudorf (and possibly in the comparable pedocomplexes of the "transition area") as well as in Stillfried (as type profile for the "dry loess landscape") the Eemian paleosol is a Bw horizon of a Cambisol. The climate during the Eemian in the neighboring loess regions to the west ("humid loess landscape") and the north (Moravia) must have been significantly moister, as evidenced by Eemian Bt horizons of former Luvisols (Fink 1956; Bronger 1976; Terhorst et al. 2002; BÁBEK et al. 2011). In contrast, in the Pannonian Basin, the last interglacial is frequently represented by Chernozems or Phaeozems (Bronger 2003; MARKović et al. 2011).

\subsection{Lower pedocomplex [P7]}

The overall brownish lower pedocomplex (P7) has a reddishbrown middle part. Clay content is enhanced and carbonates are almost completely leached. In parts pedogenic structure is well expressed and horizons with clay coatings reflect longer phases of morphological stability. In the upper half of the pedocomplex (P7a-e), sand contents are higher. Several horizons bear considerable amounts of granulite and even rock fragments were found in P7f, providing evidence for phases of geomorphological activity. The genesis of this over $2 \mathrm{~m}$ thick pedocomplex seems thus even more complex than the genesis of the upper pedocomplex (P2). The lack of chronological data however, does not allow paleoecological implications and broader correlations.

Micromorphological assessment by L. Smolíková (in KoVANDA et al. 1995) was the first approach to decipher aspects of the pedogenesis: Two superimposed paleosols were identified in the field. Microscopic analyses of both paleosols revealed clay illuviation processes and humification/bioturbation, representing forest and steppe environments respectively. Besides these findings, previous studies (e.g. FINK, 1954, 1976; Verginis 1993; KovANDA et al. 1995) have not described the remarkable complexity of the lower pedocomplex.

Below, preliminary assumptions of the main formation stages are discussed. In general, several phases of pedogenesis in steppe- to forest-steppe environments, disturbed by redeposition were found:
In the lower parts of $\mathrm{P} 7$, a dark Ah horizon (P7g) above a weak Bw horizon (P7h) are developed. The boundary area to $\mathrm{P} 8$ is enriched in secondary carbonate. This succession can be interpreted as monogenetic degraded Chernozem (Phaeozem) under (forest-)steppe conditions. Intensive redeposition and input of dust and local material is attributed to a degradation phase (P7f). Both field survey and microscopical analyses indicate phases of interglacial pedogenesis and redeposition in subunits P7c-e. Deformed clay coatings and areas with clear granular structure, as observed in thin sections, reveal clay mobilization under more humid conditions (Forest ecosystem) and bioturbation/humification in a drier climate (Steppe ecosystem). Gravel and charcoal especially in P7d, can be seen as macroscopic signs of colluvial processes. P7b-a represent a complex of steppe to forest steppe soils, which were successively buried by enhanced accumulation of eolian dust and admixture of coarser sediments of local origin.

In the context of paleoclimate, the overall more intense weathering as well as the presence of clay coatings can indicate significantly moister conditions compared to the Holocene climate in the study area or the Eemian paleoclimate. However, BRONGER et al. (1998) interpret more intensive weathering in MIS13-15 soils with prolonged pedogenesis. The thickness and complexity of P7 points to a formation during more than one interglacial, but the lack of datings allows no final conclusion whether climate or time is the main factor in respect to the grade of development.

Following the assumptions of KovandA et al. (1995), the lower pedocomplex is at least one interglacial older than the upper pedocomplex, which was formed during the Eemian (MIS 5e) and early last glacial. ZöLLER et al. (1994) assume as well its formation during the penultimate interglacial. As the oldest age according to THIEL et al. (2011b) in the loess sediment above the lower pedocomlex is $189 \pm 16 \mathrm{ka}$, the genesis of P7 in MIS 7 and/or some older interglacial(s) is most probable. In discussion of the chronology, however, possible discontinuities in $\mathrm{P} 6$ and $\mathrm{P} 7$ have to be taken into account.

It should be noted that the lower pedocomplex has been previously correlated with the "Göttweiger Verlehmungszone" (GöTZINGER 1936; FINK 1976). However, this paleosol was dated to $\geq 350 \mathrm{ka}$ (ThiEL et al., 2011b) in Göttweig-Furth. Further, the "Göttweiger Verlehmungszone" has been correlated to the KR 4 paleosol of Krems-Schießstätte (shooting range) (GöTZINGER 1936; FINK 1976); absolute ages are not available for that site, but in the loess below KR 4 the Brunhes/Matuyama reversal was found (FINk 1976). Therefore, it can be hypothesised that a major portion of the Middle Pleistocene interglacials could be recorded in Paudorf P7.

The two pedocomplexes in Paudorf thus cannot reflect two interstadials of the last glacial as postulated by LAIS (1951) and BrANDTNER $(1954,1956)$ but may be two interglacial pedocomplexes, the upper one representing the Late Pleistocene and the lower one an as yet unknown time span of Middle Pleistocene.

\section{Conclusions}

Detailed paleopedological, sedimentological and micromorphological analyses reflect the complex genesis of Paudorf locus typicus. Although this archive was seen as not favora- 
ble during its scientific history (cf. FINK 1954, 1976, BRONGER 1976), it records a well resolved and thus a considerable archive to reconstruct landscape development during Middle Pleistocene and MIS 5 in the interplay of local influences and climatically driven environmental changes. This study demonstrates that process oriented research can provide valuable insights into paleoenvironmental archives even in complex morphological settings. The scientific potential of the sequence is not only focussed on the prominent pedocomplexes, but further in the sequence of loess sediments in between. In complex loess-paleosol sequences it is next to reliable datings crucial, to trace phases of pedogenesis in order to detect phases of stability, which allow for correlation with loess-paleosol sequences of the same age.

P2, the "Paudorfer Bodenbildung", is a pedocomplex attributed to MIS 5. It is an early glacial Chernozem that developed in the redeposited (MIS 5d) Eemian Cambisol. From a paleoclimatological perspective it is important to note that P2 in Paudorf includes, like the basal soil of Stillfried a further example for Eemian Cambisols in Lower Austria.

P3-5 probably represent MIS 6. Under periglacial environmental conditions eolian dust sedimentation and (solifluidal) redeposition took place as well as pedogenesis (Cryosols) during more stable geomorphodynamic phases. To establish the genesis and age of $\mathrm{P} 6$, which includes a brownish horizon, micromorphological and geochronological investigations must be carried out. The thick lower pedocomplex (P7) provides research potential for the future, as it seems to represent local effects of few 100 ka of climatically driven sedimentation, pedogenesis and colluvial activity during the Middle Pleistocene.

\section{Acknowledgements}

We would like to thank Simon Meyer-Heinze, Markus Hörschlein and Katja Wiedner for support during field work. Christa Hermann and Maxime Farin are thanked for assistance with grain size analyses. The competent advice of Karin Wriessnig was highly appreciated in the laboratory. Dr. Sergey Sedov gave valuable review comments and was always open for fruitful discussions. Furthermore, we are grateful for the helpful review of Dr. Holger Kels. Finally we thank Hazel Sprafke for linguistic support.

\section{References}

Ad-Hoc-Arbeitsgruppe Boden (2005): Bodenkundliche Kartieranleitung. - 5. Aufl., 438 pp.; Hannover.

Anghelinu, M. \& NiţĂ, L. (2012): What's in a name: The Aurignacian in Romania. - Quaternary International, in press. doi:10.1016/j. quaint.2012.03.013.

Antoine, P., Rousseau, D.-D., Moine, O., Kunesch, S., Hatté, C., Lang, A., Tissoux, H. \& ZöLler, L. (2009): Rapid and cyclic aeolian deposition during the Last Glacial in European loess: a high-resolution record from Nussloch, Germany. - Quaternary Science Reviews, 28: 2955-2973.

BÁBEK, O., ChLACHUlA, J. ¿ GRYGAR, T.M. (2011): Non-magnetic indicators of pedogenesis related to loess magnetic enhancement and depletion: Examples from the Czech Republic and southern Siberia. - Quaternary Science Reviews, 30/7-8: 967-979.

BARTA, G. (2011): Secondary carbonates in loess-paleosoil sequences: a general review. - Central European Journal of Geosciences, 3/2: 129-146.

BAYER, J. (1909): Jüngster Löß und paläolithische Kultur in Mitteleuropa. Jahrbuch für Altertumskunde III: 149-160.

BAYER, J. (1927): Der Mensch im Eiszeitalter. - 452 pp.; Wien (Deuticke).
Bıbus, E. (1974): Abtragungs- und Bodenbildungsphasen im Rißlöß. - Eiszeitalter und Gegenwart, 25: 166-182.

Bibus, E. (2002): Zum Quartär im mittleren Neckarraum - Reliefentwicklung, Löß/Paläobodensequenzen, Paläoklima. - Tübinger Geowissenschaftliche Arbeiten, D8: 236 pp.

BRANDTNER, F. (1954): Jungpleistozäner Löß und fossile Böden in Österreich - Eiszeitalter und Gegenwart, 4/5: 49-82.

BRANDTNER, F. (1956): Lößstratigraphie und paläolithische Kulturabfolge in Niederösterreich und in den angrenzenden Gebieten. - Eiszeitalter und Gegenwart, 7: 127-175.

Bronger, A. (1970): Zur Mikromorphologie und zum Tonmineralbestand von Böden ungarischer Lößprofile und ihre paläoklimatische Auswertung. - Eiszeitalter und Gegenwart, 21: 122-144.

BRONGER, A. (1976): Zur quartären Klima- und Landschaftsentwicklung des Karpatenbeckens auf (paläo-)pedologischer und bodengeographischer Grundlage. - Kieler Geographische Schriften, 45: 268 pp.

Bronger, A., Winter, R. \& Sedov, S. (1998): Weathering and clay mineral formation in two Holocene soils and in buried paleosols in Tadjikistan: towards a Quaternary paleoclimatic record in Central Asia. - Catena, 34/1-2: 19-34.

Bronger, A. (2003): Correlation of loess-paleosol sequences in East and Central Asia with SE Central Europe: towards a continental Quaternary pedostratigraphy and paleoclimatic history. - Quaternary International, 106-107: 11-31.

Buylaert, J.-P., Jain, M., Murray, A.S., Thomsen, K.J., Thiel, C. ひ SohbaTI, R. (2012): A robust feldspar luminescence dating method for Middle and Late Pleistocene sediments. - Boreas, 41/3: 435-451.

DIN ISO 10693. Bodenbeschaffenheit - Bestimmung des Carbonatgehalts Volumetrisches Verfahren (ISO 10693:1995).

Einwögerer, T., Friesinger, H., Händel, M., Neugebauer-Maresch, C. Simon, U. \& Teschler-Nicola, M. (2006): Upper Paleolithic infant burials. - Nature, 444: 285.

FINK, J. (1954): Die fossilen Böden im österreichischen Löß. - Quartär, 6: 85-108.

FINK, J. (1956): Zur Korrelation der Terrassen und Lösse in Österreich. - Eiszeitalter und Gegenwart, 7: 49-77.

FINK, J. (1960): Leitlinien einer österreichischen Quartärstratigraphie. - Mitteilungen der Geologischen Gesellschaft in Wien, 53: 249-266.

FINK, J. (1961): Die Gliederung des Jungpleistozäns in Oesterreich. - Mitteilungen der Geologischen Gesellschaft in Wien, 54: 1-25.

FINK, J. (1976): Exkursion durch den österreichischen Teil des nördlichen Alpenvorlandes und den Donauraum zwischen Krems und der Wiener Pforte. (Mitteilungen der Kommission für Quartärforschung der Österreichischen Akademie der Wissenschaften, 1). - 113 pp.; Wien.

Fink, J. \& KuKLA, G.J. (1977): Pleistocene Climates in Central Europe: At Least 17 lnterglacials after the Olduvai Event. - Quaternary Research, 7: 363-371.

Frechen, M., Zander, A., Cilek, V. \& Ložek, V. (1999): Loess chronology of the Last Interglacial/Glacial cycle in Bohemia and Moravia, Czech Republic. - Quaternary Science Reviews, 18: 1467-1493.

GEOINFO NÖ: NÖ-Atlas 3.0. - Karte: Geländehöhe (Laserscan). - www.intermap1.noel.gv.at.

Geologische Bundesanstalt (ed., 2002): Niederösterreich. Geologische Karte 1:200 000 mit Kurzerläuterung. Geologie der österreichischen Bundesländer.

GöTzINGER, G. (1936): Das Lößgebiet um Göttweig und Krems an der Donau. - In: GöTZINGER, G. (Ed.): Führer für die Quartär-Exkursionen in Österreich. Geologische Bundesanstalt, 1: 1-11.

Haesaerts, P., Damblon, F., Bachner, M. \& Trnka, G. (1996): Revised stratigraphy and chronology of the Willendorf II sequence, Lower Austria. - Archaeologia Austriaca, 80: 25-42.

IUSS WORKING GROUP WRB (2006): World reference base for soil resources 2006 (FAO - World Soil Resources Reports, 103). - 132 pp.; Rome.

Koch, R. \& Neumeister, H. (2005): Zur Klassifikation von Lößsedimenten nach genetischen Kriterien. - Zeitschrift für GeomorphologieN.F., 49/2: 183-203.

KovAnDA, J., SMOLÍkovÁ, L. ¿ HoRÁčEK, I. (1995): New data on four classic loess sequences in Lower Austria. - Sborník geologických věd, Antropozoikum, 22: 63-85.

LAIs, R. (1951): Über den jüngeren Löß in Niederösterreich, Mähren und Böhmen. - Berichte der Naturforschenden Gesellschaft zu Freiburg i. Br., 41: 119-178.

Lisiecki, L. E. ひ M. E. RAYmo (2005): A Pliocene-Pleistocene stack of 57 globally distributed benthic d18O records. - Paleoceanography, 20: 1-17. Marković, S.B., Oches, E., Sümegi, P., Jovanović, M. \& Gaudenyi, T. 
(2006): An introduction to the Middle and Upper Pleistocene loesspaleosol sequence at Ruma brickyard, Vojvodina, Serbia. - Quaternary International, 149: 80-86.

Marković, S.B., Hambach, U., Catto, N., Jovanović, M., Buggle, B. Machalett, B., Zöller, L., Glaser, B. \& Frechen, M. (2009): Middle and Late Pleistocene loess sequences at Batajnica, Vojvodina, Serbia. Quaternary International, 198: 255-266.

Marković, S.B., Hambach, U., Stevens, T., Kukla, G.J., Heller, F., McCoy, W.D., Ochses, E.A., Buggle, B. \& Zöller, L. (2011): The last million years recorded at the Stari Slankamen (Northern Serbia) loess-palaeosol sequence: revised chronostratigraphy and long-term environmental trends. - Quaternary Science Reviews, 30: 1142-1154.

Matura, A. (2006): Böhmische Masse. - In: Wessely, G. (Ed): Niederösterreich (Geologie der Österreichischen Bundesländer). Geologische Bundesanstalt, Wien: 25-39.

MeIJs, E.P.M. (2002): Loess stratigraphy in Dutch and Belgian Limburg. Eiszeitalter und Gegenwart, 51: 114-130

Neugebauer-Maresch, C. (1993): Zur altsteinzeitlichen Besiedlungsgeschichte des Galgenberges von Stratzing/Krems-Rehberg. - In: ArchäologieÖsterreichs. Mitteilungen derÖsterreichischen GesellschaftfürUrund Frühgeschichte, 4: 10-19.

Noll, M., Leitner-Wild, E. \& Hille, P. (1994): Thermoluminescence Dating of Loess Deposits at Paudorf, Lower Austria. - Quaternary Geochronology (Quaternary Science Reviews), 13: 473-476.

PAzONYI, P (2004): Mammalian ecosystem dynamics in the Carpathian Basin during the last 27,000 years. - Palaeogeography, Palaeoclimatology, Palaeoecology, 212: 295-314.

PÉcsi, M. (1990): Loess is not just the accumulation of dust. - Quaternary International, 7/8: 1-21.

PÉCsI, M. \& Richter, G. (1996): Löss. Herkunft - Gliederung - Landschaften - Zeitschrift für Geomorphologie, Supplementband, 98: 391 pp.

Penck, A. ひ Brückner, E. (1909): Die Alpen im Eiszeitalter 1. - 393 pp.; Leipzig (Tauchnitz)

Peticzka, R., Riegler, D. ¿ Holawe, F. (2009): Exkursionsführer - 28. Jahrestagung des Arbeitskreises Paläopedologie der Deutschen Bodenkundlichen Gesellschaft, 21. bis 23. Mai 2009 in Wien. - 68 pp.; Wien. Unpublished.

Preusser, F. \& Fiebig, M. (2009): European Middle Pleistocene loess chronostratigraphy: Some considerations based on evidence from the Wels site, Austria. - Quaternary International, 198: 37-45.

Pye, K. \& Sherwin, D. (1999): Loess. - In: Goudie, A. S., Livingstone, I. \& Stokes, S. (Eds.): Aeolian Environments, Sediments and Landforms. Wiley \& Sons: 213-238.

Retallack, G.J. (2001): Soils of the Past. An introduction to paleopedology. - 2nd ed., 404 pp.; Oxford (Blackwell).

Rohdenburg, H. (1964): Ein Beitrag zur Deutung des „Gefleckten Horizontes". - Eiszeitalter und Gegenwart, 15: 66-71.
Scholger, R. \& Terhorst, B. (2011): Paläomagnetische Untersuchungen der pleistozänen Löss-Paläobodensequenz im Profil Wels-Aschet. - In: Van Husen, D. \& Reitner, J. (eds.): Die Löss-Sequenz Wels/Aschet Ein Referenzprofil für das Mittel- und Jungpleistozän im nördlichen Alpenvorland (MIS 16 bis MIS2) (Mitteilungen der Kommission für Quartärforschung der Österreichischen Akademie der Wissenschaften, 19): 47-61.

Schönhals, E., Rohdenburg, H. ש Semmel, A. (1964): Ergebnisse neuerer Untersuchungen zur Würmlöß-Gliederung in Hessen. - Eiszeitalter und Gegenwart, 15: 199-206.

Semmel, A. (1968): Studien über den Verlauf jungpleistozäner Formung in Hessen. -Frankfurter Geographische Hefte, 45: 133 pp.

SMAlley, I., MARKović , S.B. \& Svirčev, Z. (2011): Loess is [almost totally formed by] the accumulation of dust. - Quaternary International, 240: $4-11$.

Terhorst, B. (2007): Korrelation von mittelpleistozänen Löss-/Paläobodensequenzen in Oberösterreich mit der marinen Sauerstoffisotopenkurve. - E \& G, Quaternary Science Journal, 56: 172-185.

Terhorst, B., Frechen, M. \& Reitner, J. (2002): Chronostratigraphische Ergebnisse aus Lößprofilen der Inn- und Traun-Hochterrassen in Oberösterreich. - Zeitschrift für Geomorphologie N.F., Supplementband, 127: 213-232.

Terhorst, B., Thiel, C., Peticzka, R., Sprafke, T., Frechen, M., Roetzel, R., Neugebauer-Maresch, C. \& Fladerer, F.A. (2011): Casting new light on the chronology of the loess/paleosol sequences in Lower Austria. - E \& G, Quaternary Science Journal, 60/2-3: 270-277.

Thiel, C., Buylaert, J.-P., Murray, A.S., Terhorst, B., Hofer, I., TsukamoTO, S. \& FrEchen, M. (2011a): Luminescence dating of the Stratzing loess profile (Austria) - Testing the potential of an elevated temperature post-IR IRSL protocol. - Quaternary International, 234: 23-31.

Thiel, C., Buylaert, J.-P., Murray, A. S., Terhorst, B. Tsukamoto, S., FrECHEN, M. \& SPRAFKe, T. (2011b): Investigating the chronostratigraphy of prominent palaeosols in Lower Austria using post-IR IRSL dating. - E \& G, Quaternary Science Journal, 60/1: 137-152.

VERGINIS, S. (1993): Lössakkumulation und Paläoböden als Indikatoren für Klimaschwankungen während des Paläolithikums (Pleistozän). Mit ausgewählten Beispielen aus Niederösterreich. - In: NeugebauerMARESCH,C.(Ed.):AltsteinzeitimOstenÖsterreichs(Wissenschaftliche Schriftenreihe Niederösterreich, 95/96/97), 2. Aufl.: 13-30.

Viscarra Rossel, R.A., Minasny, B., Roudier, P. \& McBratney, A.B. (2006): Colour space models for soil science. - Geoderma, 133: 320-337.

Zöller, L., Oches, E. A. \& McCoy, W. D. (1994): Towards a revised chronostratigraphy of loess in Austria with respect to key sections in the Czech Republic and in Hungary. - Quaternary Geochronology (Quaternary Science Reviews), 13: 465-472. 